\title{
Survey and Thinking on Entrepreneurship education of Local College Students
}

\author{
Wang Hongmei
}

Social Science Department Dezhou University Dezhou, China

\begin{abstract}
the economic and social development is not only in demand of job hunters who fit in with certain positions but also needs badly the job creators who develop new job opportunities through setting up their own business. The popularization of higher education has put forward new requirements on traditional application talents. According to this, to carry out the entrepreneurial education in the universities becomes a proposition of the current era. Under the influence of entrepreneurship education tide in foreign and domestic universities, how to effectively carry out entrepreneurial education, especially how the choice of entrepreneurial education mode can embody the pertinence, adaptability, uniqueness and effectiveness becomes a worth exploring topic for the local universities. According to the investigation, an elaborative exposition follows.
\end{abstract}

Index Terms: local universities; College students; Entrepreneurship education

(C) 2012 Published by MECS Publisher. Selection and/or peer review under responsibility of the International Conference on E-Business System and Education Technology

\section{Introduction}

Overview of the current trend of economic and social development and situation of higher education reform, in order to meet needs of changes of the talent specification during the period of the social and economic structure transition, it is an active response to develop entrepreneurship education in colleges in order to build an innovation-oriented country, and it is also an innovation measure of teaching reform on college education, and of improving the training quality.

According to statistics from Ministry of Education, graduates in 2003, the first session after the expansion of enrollment in universities and colleges, tolled up to 2.12 million while in 2010 more than 6.30 million students graduated from national ordinary universities and colleges, 2.97 times larger than that of 2003. Moreover, the negative effects of the world financial crisis add up to the severe situation of graduate employment. Faced with the severe employment situation, college students starts to open up their own business, which draws the attention from all fields, and also touch off our interest in launching a research. Based on this, from March 2010 to June 2010, we conducted a survey with the theme of entrepreneurship education, targeting the current students in DeZhou University. 


\section{BASIC INFORMATION}

The survey targeted at undergraduate and junior college students covered 10 different kinds of subjects such as Arts, science, engineering, economy, management. In the research, firstly we confirm the students of certain investigated major then before class relevant teacher would give out the questionnaire list to the students randomly .After finishing the form they handed it in immediately. All the 800 questionnaires were taken back, with 764 valid forms accounting for $95.5 \%$. In the survey, there were 340 boys and 424 girls accounting for $44.5 \%$ and $55.5 \%$ of the effective samples respect; 610 undergraduates and 154 junior college students with the proportion of $79.8 \%$ and $20.16 \%$.The report adopts qualitative analysis and descriptive statistical analysis method .

\section{SURVEY DATA ANALYSIS}

\section{1 Understanding of entrepreneurship.}

Investigation shows that $93.5 \%$ of respondents claim the knowledge of basic concepts of entrepreneur etc, but $92 \%$ of respondents acquire little further understanding, only $7.8 \%$ know more about them, another $0.2 \%$ students even have not heard of them. Thus, in recent years, the authorities, especially the higher education field, launch the activities such as pilot and exploration process of entrepreneurship education, propaganda of relevant information etc, which to a certain extent lay a comparatively great impact on college students. As an important higher education teaching reform, entrepreneurship education, for various universities, has become more and more important approaches of human talent training reform and entrepreneurial consciousness and entrepreneurial concepts has gradually been involved in the occupational perception of college students.

\section{2 Expectations of entrepreneurship.}

Survey figures showed that $90 \%$ respondents hold the ideas of starting up their own business, but among them $81 \%$ choose to begin two or three years after graduation and $17 \%$ plan to venture immediately after graduation. It is not only staged achievement through developing entrepreneurship education, but also lays a good foundation for the further improvement of entrepreneurship education. Only 2 percent of the students said they have not thought of starting a business or will never do it.

\section{3 Cognition of entrepreneurial setback education.}

$30.8 \%$ of respondents believed that entrepreneurial setback education was of vital importance, $46.5 \%$ of them thought it was important, amounting to $77.3 \%$. It suggests that college students hold a quite appropriate understanding about the important role setback education playing in their entrepreneurship and life development, and they expect to accept setback education while doing pioneering work.

\section{4 On the cultivation of independence and self-confidence.}

$30.8 \%$ of respondents believed that, education of self-confidence and independence was extremely important, $50.4 \%$ of them believed self-confidence and independence education was important, amounting to $81.4 \%$. It suggests that university students have already realized that confidence and independence have a great impact on them in life development and entrepreneurial process. In entrepreneurial education they hope to strengthen their self-confidence and independence during the training and cultivation process. 


\section{5 Entrepreneurship and capacity.}

$80.0 \%$ of survey respondents underlined all the choices listed below the question including psychological quality and the ability to communicate with others, wide sphere of vision, negotiations capability and management ability. $5.6 \%$ selected only the ability to communicate with people, $3.2 \%$ of the students did not choose negotiation ability, and all the students chose the communicative ability. All above show that college students recognized the importance of the ability to communicate with people objectively and rationally, which is roughly coincided with social general consensus. It also reflects the students are not satisfied with their abilities of communicating with people in real life and interpersonal effect it has achieved, which needs further improvement. Thus it is necessary to put communication with people into the content of entrepreneurial education to enhance communicative skill training and improve the students' communicative ability.

This question also shows that students exaggerated the importance of ability to communicate with people in the undertaking business. To start an undertaking needs to make contacts with people, requires mutual understanding and support in various ways. Although it is of great meaning for most of new enterprises' success to master the ability to know what someone else needs and persuade others euphemistically studies show that many successful promoters in this respect performed not very prominently.

\section{6 Training focus of entrepreneurial education.}

In the survey, $38.5 \%$ of college students chose the cultivation of students' entrepreneurial skills and personality quality, $19.4 \%$ the students chose to direct student to specific entrepreneurship practice, $4.6 \%$ of students added communication with successful personage of their own accord. Problems show that students tend to practice more, hoping to gain necessary skills in entrepreneurship education, have the opportunity to participate in entrepreneurship practice in personal, and share the experience and lessons with each other during entrepreneurial process. This suggests that schools and teachers should create entrepreneurial environment and atmosphere, form the base and platforms for students to practice themselves, and establish close contact with different social professions. During contacts and exchanges with relevant personage, schools and teachers need to arouse students' enthusiasm, exercise students' ability in business startup, make the contribution to conveying a batch of entrepreneurial type qualified human talents to the society in the future.

\section{7 Concerning the order of the methods in the cultivation of innovative thinking}

Contacting frequently with and learning from successful personage (52\%), reading innovation stories about successful personage (39.4\%), learning innovation methods (7.6\%). The choice of this question indicates that students show much concern on how to stimulate innovative inspiration in face of specific problems, and generally get rid of the misunderstanding of innovate for innovation, in this aspect college students are quite sensible.

\section{8 Concerning the selection of entrepreneurship education mode}

College students prefer practice. Of the way of obtaining the entrepreneurial knowledge and skills, $63 \%$ of students turn to the choice of activity plus training, $37 \%$ choose to practice personally.

\section{ANALYSIS OF CURRENT SITUATION}

Entrepreneurship education is a very complicated practical proposition. Different countries, different regions and different schools apply different practice modes of entrepreneurship education. Due to plenty of differences between Chinese and western higher education, entrepreneurship education patterns of foreign universities and colleges such as Stamford mode, MIT mode, Singapore mode and so on all do not fit in with current situation of our colleges and characteristics of Chinese students. Even in China, owing to the great number of colleges and universities, there are also many differences in schooling levels and characteristics and students of different 
levels and characteristics and so on. Therefore, exploration of entrepreneurial education in domestic universities is also conducted in different forms. But through an overview of domestic universities, entrepreneurship education can be roughly divided into two parties: one is colleges affiliated to ministry and key universities with the tradition and resources to their advantage .Their entrepreneurship education started much earlier. Taking 9 pilot colleges, the state, education administrative department, and the colleges themselves have invested more on the education, which has basically formed unique scale and characteristics. The other is the local colleges and universities, accounting for absolutely the largest portion of schools in the whole country, with the tradition and resources relatively to their disadvantage. They develop entrepreneurial education with comparatively high initiatives and take actions more actively, but always could not get rid of the habit of copying the modes and measures of western universities or domestic key universities, or entrepreneurship education pilot colleges, thus leading to a series of problems such as the mismatch of education modes, weak adaptability and practicability etc [1].

Four striking problems existing in research and practice of entrepreneurship education in domestic local universities:

The first one is the inadequate pertinence and insufficient localization. With too much reference to the entrepreneurship education theories of foreign students, and little independent theoretical innovation and combination with local specific conditions, the education mode and method is too simplified, and combines little either with objective reality of Chinese students or with otherness in students of different levels and different professional disciplines background.

The second one is the lagging content, the simple method, the unsatisfied effects of entrepreneurship education; and the low rate of successful entrepreneurship practice. For the time being, most colleges in our country haven't carry out special education course, only a few schools like Tsinghai University etc open up entrepreneurship center to offer assistance to students. For many schools, they have said more about entrepreneurship education than taken into action, according to incomplete figures, only 2-3\% college students succeeded in starting their own business. Improving success rate of entrepreneurship practice earnestly is a never-to-be-evaded problem.

The third one is separation between entrepreneurial education and professional disciplines education. Now our entrepreneurship education is outside of "formal education", and a kind of 'amateur education' taking up extracurricular time, and places more emphasis on lectures than on education, more on theory than on practice. And it still could not bind with specialized subject education organically, and fail to be integrated into the whole education system, causing superficial passion yet insufficient internal strength of students; many of them have the idea of opening up their own business but few choose to put it into practice [2].

The fourth one is weak teaching force. Teachers who give entrepreneurship course should have entrepreneurial or investment experiences, and should be familiar with the enterprise operation. But at the moment, half of the teachers engaged in entrepreneurial education and training course come from two aspects: one kind are teachers who originally engaged in teaching the subject of enterprise management, the other are teachers who give students employment guiding. These two kinds of teachers have a common weakness, that is, lack of entrepreneurial experience and practice capacities. It may be unavoidable to sink into "an armchair strategist" awkward state while educating and training the student on how to found and operate an enterprise [2].

\section{SUGGESTIONS AND COUNTERMEASURES}

Suggestions and countermeasures on how to promote the development of entrepreneurship education for local colleges in a healthy way are as following.

After nearly a decade of exploration in entrepreneurial education, universities in China have accumulated the preliminary experience, and are stepping into the critical period of the rational development. According to social needs of China's future and development targets of entrepreneurship education, combining with the above findings, and viewing the current existing problems, we put forward some countermeasures and suggestions for local university education to promote the healthy development of entrepreneurship. 


\section{1 To establish perfect career education curriculum system.}

The education administrative department and colleges and universities could consider taking entrepreneurship education into the teaching blueprint, establish entrepreneurship education courses system, construct the whole course, and increase upstream and downstream extensibility of curriculum and teaching content relating to entrepreneurship education.

In the targets of curriculum, with orientation of new quality standards and training goal of entrepreneurial type talent, they need to strengthen the reform of curriculum system, structure and content, to develop practical, composite, entrepreneurial type of talents who can obtain both employment and entrepreneurial skills.

In the curriculum contents, to pose emphasis on exercising and training students' pioneering consciousness and pioneering psychological quality, and strive to cultivate entrepreneurial ability and impart knowledge of working practice.

In the curriculum form, to combine the subject course and activity course, the explicit course and recessive course, and make programs tutoring students' entrepreneurship generally [3].

\section{2 To build practice platform actively.}

Entrepreneurship education is a kind of practical education, the education effects must speak through facts. Entrepreneurship education must not just stay in "an armchair strategist" level, simple entrepreneurship knowledge and education theory is far not enough. Therefore, entrepreneurship education must have practical platform, so that students can go to try, experience and practice as much as possible. Therefore, colleges must reform the content of education course, that is, while continuing to adhere to the education of college students in theoretical knowledge, they still need increase entrepreneurial activities and add more entrepreneurship practice contents, and build a good platform for students to attend entrepreneurial activities and practices, enhance contact between students and social entrepreneur personage, deepen the students' sense of reality on entrepreneurship, and stimulate students' interest and passion to venture.

Firstly, based on the college students' majors, interests and specialties, universities need develop entrepreneurship practice base, making it place for teachers to demonstrate teaching, hands-on position for students and entity of creating economic effectiveness, forming a "study-practice-innovative" trinity for students.

Secondly, establishing entrepreneurial companies and enterprises that schools invest, teachers guide and students administrate. College students can take part in the operating management of economic entities (such as companies, enterprises etc), learn how to start up and keep their businesses in a specific marketing environment and thus accumulate first-hand entrepreneurship experience.

\section{3 To strengthen specialized construction of teaching force of entrepreneurship education.}

Teachers' quality determines their teaching quality; teachers' level decides education level. To cultivate the high-quality pioneering talents will be in demand of building a high level of entrepreneurship education teacher force. On one hand, to make teachers master entrepreneurship education concepts, arouse teachers to actively reform teaching methods, and explore effective ways of enterprising education. On the other hand, we can engage social entrepreneurs, successful personage in doing pioneering work, and technologically innovative experts as part-time teachers in schools, adopting the university-enterprise cooperation way. Meanwhile, we should actively explore the colorful innovation practice, strengthen the international and domestic innovation in the field of academic exchange and seminars and scientific research in order to bring up a grand high- level entrepreneurship education faculty [4].

\section{4 To build good environment for students' entrepreneurship.}

At present our country has issued a series of preferential policy which encourage self-employed students. However, in real life, the road of college students' autonomous entrepreneurship is still twisting and difficult. In addition to their own limitations, the lack of an ordered, external environment which can encourage students to 
be the ones who "want, dare, and be able to" start up their own business, has become the biggest barrier for students' self-employment. At the moment, government's preferential policies on supporting the students in business lack strength in maneuverability. Some policies changed in the implementation and operation process, especially in the business field, financing channels and tax incentives etc which are some key problems relating to the students' entrepreneurship. College students who would like to be self-employed didn't enjoy the genuine support from government, causing the abortion of entrepreneurial dreams. Starting an undertaking becomes the "hot" choice for college students in this "difficult" employment time and it is even to be their last choice. A minority of success and a majority of failure show that the students who start their own business still have a long way to go. University students' external environment of pioneering work should be improved urgently [5].

To broaden the college students' employment channels and promote the university students' own undertaking, we must build a good business environment which can ensure, promote and enable to pioneer. First of all, we should encourage and support the publicity of college students' self-employed policies and guide students to change employment concept, create a social atmosphere that propagating entrepreneurship glorious, advocating success, tolerating failure. Second, the government, universities and enterprises should promote preponderant industry or potential advantage industry project to college students through various channels providing suitable development soil to make students pioneering more with pertinence and the possibility to succeed. Finally, we should popularize and publicize successful models of governments and colleges that encourage and support selfemployed students in business in order to set an example for college students and offering a platform for reference and communication entrepreneurial experience[1].

\section{5 Relying on the advantages of local resources.}

Local universities are the ones which are built relying on local resources, serving local first, and bearing regional features. These schools cannot be compared with universities in running the comprehensive level, but they have their own distinct features and comparative advantages. They combine closely with the local and easily integrate with local resources to serve for education and teaching. Therefore, the regional characteristics of local colleges and universities are precious resources in developing entrepreneurship education. Local colleges and universities should reveal its entrepreneurship education characteristics on this background.

\section{CONCLUSION}

Entrepreneurship education is a new proposition and a social topic relating to such a people livelihood project as employment. It cannot be solved simply by the own strength of universities. But as talent-training institutions with social industry properties, the colleges and universities must practice earnestly, play the leading role in education and promote development of the entrepreneurship education actively.

\section{Referrences}

[1] XiaChunYu Research and thinking of local university students in entrepreneurship education - taking Zhejiang Province as an example.Journal of Changchun University (higher education research edition), 2009 (12) : 31-32.(in Chinese)

[2] SongYaLi Existing problems and countermeasures weblogs of students entrepreneurship education , new western by 2010, (14): 175. (in Chinese)

[3] LiBing Under the new situation the students entrepreneurship education series. The BBS, people by 2010, (8): 29-291. (in Chinese)

[4] ZhangHongJun Difficulties and countermeasures on development of students entrepreneurship education.j education exploration by 2010, (4): 66-68. (in Chinese)

[5] HuSongNian.Development and characteristics of foreign students in entrepreneurship education.journal of higher education development and evaluation by 2010, (4): 14-16. (in Chinese) 